\title{
Plant species composition and diversity depending on piospheres and seasonality in the southern rangelands of Kenya
}

\author{
S. O. Jawuoro* , O. K. Koech, G. N. Karuku and J. S. Mbau
}

\begin{abstract}
Introduction: Scarcity of water in the rangelands of Kenya has led to the introduction of piospheres. Previous research has however produced contrasting results on the effects of piospheres and seasonality on ShannonWiener's diversity index, and therefore, this information is still deficient. In this study, the impact of these piospheres on plant species composition, diversity, and richness was assessed.

Methods: Vegetation sampling was done during both the long rains (April) and the dry season (August). Three piosphere types (dam, trough, and a seasonal river) were studied using $0.25 \mathrm{~m}^{2}$ quadrats to sample vegetation at intervals of $20 \mathrm{~m}$ along 100-m transects. Four 100-m transects were used per piosphere (north, east, south, and west directions). Shannon-Wiener's diversity index was used to determine species richness and composition. Twoway ANOVA was used to determine if piospheric distance had an effect on species diversity, richness, and evenness using GenStat 15th edition.

Results: A total of 22 grasses and 29 forbs were recorded in the study area. The most abundant grasses near the piospheres were Eragrostis tenuifolia (12.9\%) and Cynodon dactylon (10.6\%). E. tenuifolia is an increaser species and was therefore most abundant in areas of severe grazing while $C$. dactylon has been known to be tolerant to grazing. The most abundant forbs were Crotalaria brevidens (37.5\%). The Shannon-Wiener diversity index significantly increased $(F=25.07, P=0.001)$ with distance from the three piospheres owing to the high grazing intensity near the piospheres and was significantly different between piospheres, being higher $(F=10.05, P=0.001)$ at $20 \mathrm{~m}$ from the river $(1.2 \pm 0.1)$ compared to a similar distance from the dam $(0.9 \pm 0.1)$ and the trough $(0.8 \pm 0.2)$. This was probably because the trough was smaller in size compared to the other piospheres, thereby concentrating more grazing animals per unit area and causing a greater impact on plant species.

Conclusions: The study demonstrated that species diversity, richness, and evenness were low near the piospheres due to heavy grazing. Similarly, the lowest species diversity, richness, and evenness were recorded near the trough compared to the dam and the river. This study therefore recommends that range reseeding and rest period be done to rehabilitate degraded areas and facilitate plant regeneration. Larger piospheres should also be used to minimize animal impact per unit area.
\end{abstract}

Keywords: Piosphere, Species composition, Shannon-Wiener diversity, Species richness, Rangelands

\footnotetext{
* Correspondence: stanleyjawuoro@gmail.com

Department of Land Resource Management and Agricultural Technology

(LARMAT), University of Nairobi, P.O. Box 29053-00625, Nairobi, Kenya
} 


\section{Introduction}

Piosphere is defined as the radial pattern of differential grazing and the associated animal impact which develops around the water points (Lange 1969; Todd 2006). These patterns formed around piospheres form a basis for studying the effects of livestock grazing and differentiating them from other environmental factors (Todd 2006). Piospheres have an effect on both soil and vegetation. Impacts on soil include, among others, alterations to soil nutrients such as organic carbon, total nitrogen and $\mathrm{pH}$ (Smet and Ward 2006; Shahriary et al. 2012), soil compaction, reduction of soil aggregate stability and changes in soil texture. The effects on vegetation include increased shrub mortality, plant defoliation, alterations to species composition and demography (Riginos and Hoffman 2003), and changes in herbaceous vegetation (Egeru et al. 2015). Plant defoliation by livestock and wildlife grazing around these piospheres increases palatable species' mortality, thereby reducing their ability to favorably compete with less palatable alien and exotic species (Hunt et al. 2002; Shahriary et al. 2012). Further, trampling reduces seed production and seedling establishment in the rangelands (Chaichi et al. 2005; Amiri et al. 2008). Grazers also change rangeland vegetation through deposition of urine and feces and by dispersing plant seeds and propagules (Shahriary et al. 2012).

The attempt to create a generalized pattern of effect of piospheres on vegetation across the world is based on the perception that plant species with similar morphological and physiological traits should respond similarly when exposed to grazing (Brooks and Matchett 2006; Todd 2006). Piospheric studies on species composition, richness, and diversity indices have been done in most parts of the world including Australia (Landman et al. 2012), Asia (Shahriary et al. 2012), Southern Africa (Todd 2006), Northern Africa (Tarhouni et al. 2007), and Uganda (Egeru 2014; Egeru et al. 2015). Nevertheless, there have been no studies conducted in Kenya, especially in the southern rangelands where water interventions have been widely undertaken to alleviate water shortage and enhance pastoral livelihoods (Opiyo et al. 2015). It is known that haphazard introduction of piospheres without ecological considerations lead to rangeland degradation (Brooks and Matchett 2006). This study therefore sought to establish the effect of piospheres on plant species composition, diversity, and richness in the southern rangelands of Kajiado County, Kenya, in order to provide insights for designing water intervention strategies that will enhance pastoral livelihoods without adversely affecting vegetation.

\section{Methods}

Study area

The study was done in Kiserian area, Kajiado County, Kenya, located within $36^{\circ} 5^{\prime}$ and $37^{\circ} 5^{\prime}$ east and $1^{\circ}$ and $3^{\circ}$ south (Fig. 1). The range of altitude in this county

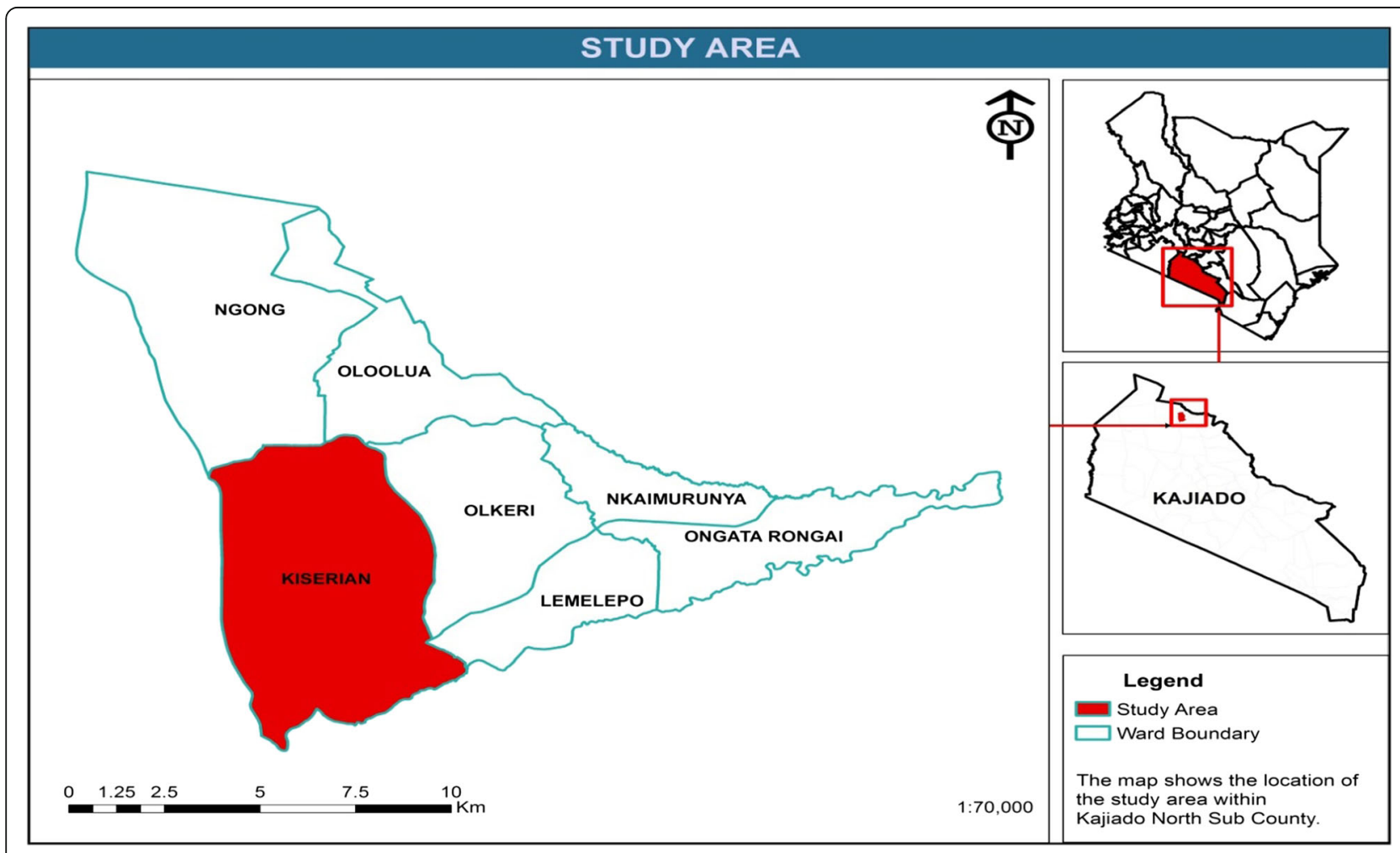

Fig. 1 The study area in Kiserian area, Kajiado County, Kenya 
ranges between 1580 and 2460 masl. The annual rainfall received ranges from 300 to $1250 \mathrm{~mm} /$ year (Kareri 2013). Rainfall is bimodally distributed. The long rains (first rains) fall between March and May whereas the short rains (second rains) are received from October to December (Ogutu et al. 2013). The minimum and maximum mean diurnal temperatures are 10 and $24{ }^{\circ} \mathrm{C}$ respectively (Krhoda 2002). The ratio of rainfall to evapotranspiration in the area is $<0.65$ (Middleton and Thomas 1997). Kiserian is a semiarid area found within agro-ecological zone IV. Soils are mainly vertisols, sticky when wet, and forming large cracks during dry seasons (de Leeuw et al. 1991; Ombogo 2013). The most widespread plant species are Acacia mellifera; Acacia tortilis, Acacia nubica, Acacia ancistroclada, Acacia nilotica, Commiphora riparia, Commiphora africana, and Balanites aegyptiaca are the most common species (Bekure 1991).

According to the national census of the Kenya Republic (2010), about 202,651 people live in Kajiado County with a population growth rate estimated to be $4.5 \%$. Most of the residents are traditionally pastoralists (Ogutu et al. 2013). However, due to emerging socioeconomic opportunities and climate change, formal employment, cultivation, group ranching, and trade have been adopted in order to diversify income sources (Kioko and Okello 2010).

\section{Research design}

A randomized block design was used for this research with four watering points forming blocks while plots (5) were the distances from water points. Quadrats $\left(0.25 \mathrm{~m}^{2}\right)$ were the main sampling points, placed at intervals of $20,40,60,80$, and $100 \mathrm{~m}$ within a $100-\mathrm{m}$ transect from the watering point. Each treatment was replicated four times in the east, west, north, and south directions from the watering points. Two troughs, a dam, and a seasonal river of similar durations of use and management type were assessed. The troughs were smaller in size compared to the dam and the river and could have an impact by increasing grazing pressure around it due to greater animal concentration. The river was a natural water system and was therefore used as a control to provide a basis of comparison with the artificially created water sources (dam and trough).

\section{Vegetation sampling}

Plant species diversity, richness, and evenness are affected by climatic variables such as rainfall. Vegetation sampling was therefore done in April during the long rains (wet season) and August during the dry season. Similarly, seasonal rivers are also affected by rainfall, and as such, differences in plant species diversity, richness, and evenness were expected between wet and dry spells.
However, dams and troughs were in use during both seasons, and therefore, no significant changes were expected in the vegetation attributes determined. Transects were done starting at $10 \mathrm{~m}$ away from the piosphere, to minimize edge effects, and stretched a distance of $100 \mathrm{~m}$. Four transects were used per piosphere. Plant species were assessed after every $20 \mathrm{~m}$ within $0.5 \mathrm{~m}$ by $0.5 \mathrm{~m}$ quadrats, and available species counted and recorded. Species composition was determined using their relative densities as described by Krebs (1989), using the formula

$$
\left(\frac{n_{i}}{N}\right) \times 100
$$

where $n_{i}$ is the quantity of individual species per quadrat, while $N$ is the total quantity of species within the same quadrat.

Species diversity was determined using ShannonWiener's diversity index as described by Krebs (1989). Shannon-Wiener's diversity index $\left(H^{\prime}\right)$

$$
H^{\prime}=-\sum\left[\left(\frac{n_{i}}{N}\right) \times \ln \left(\frac{n_{i}}{N}\right)\right]
$$

where $n_{i}$ is the number of individuals of each species, $N$ is the total number of individuals (or amount) for the site, and $\ln$ is the natural log of the number.

Species richness $(S)$ was calculated as the total number of species per quadrat while Pielou evenness was calculated as described by Krebs (1989).

$$
J=\frac{H \Subset}{\ln (H \Subset)_{\max }}
$$

where $H^{\prime}$ is Shannon-Wiener's diversity index for the quadrat and $\left.H{ }^{(}\right)_{\max }$ is the natural log of species richness $(S)$.

\section{Statistical analysis}

Statistical analyses were performed using GenStat 15th edition. Two-way ANOVA was used to determine if there were significant differences between means of species diversity, richness, and evenness at various piospheric distances, piospheres, and seasons. Comparison of means was done to determine if there were significant differences between treatment pairs. Tukey's HSD test was used to compare the means. Significance was obtained at $P \leq 0.05$.

\section{Results}

\section{Species composition}

The relative densities (\%) of grasses at various piospheric distances are shown in Table 1. A total of 51 herbaceous species were recorded. Among the 22 grass species recorded, 15 grass species were recorded in the dry season while 21 grass species were recorded during the wet 
Table 1 Relative densities (\%) of grass species at various piospheric distances

\begin{tabular}{|c|c|c|c|c|c|c|c|c|c|c|c|}
\hline \multirow[b]{3}{*}{ Species $(N=22)$} & \multirow[b]{3}{*}{ Distance (m) } & \multicolumn{10}{|c|}{ Relative density (\%) } \\
\hline & & \multicolumn{5}{|c|}{ Dry season } & \multicolumn{5}{|c|}{ Wet season } \\
\hline & & 20 & 40 & 60 & 80 & 100 & 20 & 40 & 60 & 80 & 100 \\
\hline Aristida adoensis & & 1.3 & 5.8 & 0.5 & 1.9 & 0.9 & NP & 0.9 & 4 & 1 & 4.1 \\
\hline Bothriochloa insculpta & & 11.5 & 6.6 & 3.6 & 4.8 & 5.5 & 4.4 & 5 & 2 & 7.6 & 6.9 \\
\hline Brachiaria lacnatha & & NP & NP & NP & NP & NP & 1.3 & NP & NP & NP & 1.4 \\
\hline Chloris pycnothrix & & 7.1 & 3.9 & 2.1 & 0.9 & 2.3 & 4.4 & NP & 2.8 & 1 & NP \\
\hline Cymbopogon excavatus & & NP & NP & NP & NP & NP & 3.9 & 0.9 & 3.2 & 1 & 3.4 \\
\hline Cymbopogon vallidus & & 1.7 & 0.9 & 2.6 & 1.9 & 2.7 & NP & NP & $N P$ & NP & NP \\
\hline Cynodon dactylon & & 11.1 & 6.2 & 2.6 & 3.9 & 2.7 & 10.1 & 5.4 & 3.6 & 2.1 & $\mathrm{NP}$ \\
\hline Digitaria macroblephara & & NP & NP & NP & NP & NP & NP & 1.8 & 8 & NP & NP \\
\hline Digitaria milanjiana & & NP & NP & NP & $N P$ & NP & NP & NP & 1.6 & 1.5 & NP \\
\hline Digitaria scalarum & & 2.6 & 1.3 & 19.3 & 21.3 & 0.9 & 7.9 & 10 & NP & 14.2 & NP \\
\hline Eragrostis tenuifolia & & 16.4 & 13.3 & 11.5 & 9.7 & 7.4 & 9.3 & 7.7 & NP & 3.6 & 2 \\
\hline Eriochloa fatmensis & & 0.8 & NP & NP & NP & NP & 7.7 & 6.3 & 11.2 & NP & 1.4 \\
\hline Hyparrhenia hirta & & 2.6 & 1.7 & 1.6 & 5.8 & 1.8 & 2.2 & 0.5 & NP & 1.1 & 2.7 \\
\hline Hyperrhenia lintonii & & 2.2 & NP & 2.1 & 3.8 & 0.5 & 1.3 & 3.6 & 29.7 & 3.6 & 9.6 \\
\hline Michrocloa kunthii & & NP & 0.8 & 1 & NP & 0.5 & NP & 0.5 & NP & 5.6 & NP \\
\hline Pennisetum mezianum & & 1.3 & NP & $N P$ & 0.97 & NP & NP & 1.8 & $N P$ & NP & NP \\
\hline Setaria holstii & & 25.7 & 24.3 & 26 & 21.3 & 37.7 & 13.6 & 17.2 & NP & 18.8 & 32.9 \\
\hline Setaria sphacelata & & NP & $N P$ & 4.7 & 1.93 & NP & 1.3 & 3.6 & 29.7 & 3.6 & 9.6 \\
\hline Setaria verticillata & & NP & NP & NP & NP & NP & 8.4 & NP & NP & NP & NP \\
\hline Sporobolus discosporus & & $N P$ & $N P$ & $N P$ & $N P$ & NP & 1.3 & 0.5 & $N P$ & NP & NP \\
\hline Sporobolus pyramidalis & & NP & 1.9 & 3.6 & 1.93 & 5.6 & NP & NP & $N P$ & 0.5 & NP \\
\hline Themeda triandra & & 15.1 & 29.2 & 18.7 & 19.3 & 30.2 & 23.4 & 36.2 & 29.7 & 38.1 & 34.3 \\
\hline
\end{tabular}

$N P$ not present

season. We found 18 perennial grasses, and 4 were annual grasses. The most dominant annual grasses (with the highest relative densities) were Chloris pycnothrix and Eragrostis tenuifolia whereas Themeda triandra, Setaria holstii, Aristida adoensis, Bothriochloa insculpta, Cynodon dactylon, and Hyparrhenia hirta were the most dominant perennial grasses. Cynodon dactylon, Eragrostis tenuifolia, Eriochloa fatmensis, Chloris pycnothrix, and Setaria verticillata were more pronounced near the watering points.

There were 29 forbs recorded during both dry and wet seasons (Table 2). Of these, 27 were recorded during the dry season while 25 forbs were recorded during the wet season. The most dominant forbs were Indigofera spicata, Indigofera volkensii, Launaea cornuta, and Glycine wightii. Among the 29 forbs recorded, 10 belonged to family Fabaceae, representing $36 \%$ of the total, while six were members of family Acanthaceae representing $18 \%$. The Lamiaceae and Labiatae families had two species each, forming $15 \%$ of the total number of forbs recorded. One species each was recorded for families Phyllanthaceae, Polygalaceae, Asteraceae, Malvaceae, Tiliaceae,
Euphorbiaceae, and Solanaceae, each family being $4 \%$ of the total forb population observed. Forbs were more pronounced around the water points.

\section{Shannon-Wiener diversity index, species richness, and Pielou evenness}

Plant species diversity, richness, and evenness at various distances from the dam, the trough, and the river are shown in Table 3. Shannon-Wiener's diversity index significantly increased $(F=25.07, P=0.001)$ with piospheric distance and was significantly different $(F=10.05, P=$ $0.001)$ between piospheres, being $(1.2 \pm 0.1)$ at $20 \mathrm{~m}$ from the river compared to a similar distance from the dam $(0.9 \pm 0.1)$ and the trough $(0.8 \pm 0.2)$. There was no significant difference $(F=0.24, P=0.622)$ in ShannonWiener's diversity index between the wet and dry seasons. Moreover, the interactions between treatments (distance $\times$ season $\times$ piosphere) were not significant $(F$ $=0.45, P=0.889$ ).

Similarly, species richness $(S)$ significantly increased $(F=17.05, P=0.001)$ with distance from all the three piospheres. Although higher species richness was 
Table 2 Relative densities (\%) of forbs at various piospheric distances

\begin{tabular}{|c|c|c|c|c|c|c|c|c|c|c|c|}
\hline \multirow[t]{3}{*}{ Species $(N=29)$} & \multirow{3}{*}{$\begin{array}{l}\text { Family distance } \\
\text { (m) }\end{array}$} & \multicolumn{10}{|c|}{ Relative density (\%) } \\
\hline & & \multicolumn{5}{|c|}{ Dry season } & \multicolumn{5}{|c|}{ Wet season } \\
\hline & & 20 & 40 & 60 & 80 & 100 & 20 & 40 & 60 & 80 & 100 \\
\hline Ajuga remota & Labiatae & NP & 1.5 & NP & NP & NP & 9.4 & NP & 4.3 & NP & NP \\
\hline Alyscarpus rogusus & Fabaceae & 8.3 & 7.7 & NP & NP & 3.1 & 0.9 & 3.3 & 6.4 & 1.2 & 3.2 \\
\hline Barleria acanthoides & Acanthaceae & NP & 1.5 & NP & 2.9 & NP & 0.9 & 1.1 & 1.1 & NP & 1.1 \\
\hline Becium obovatum & Labiatae & NP & NP & NP & NP & 1.5 & 1.9 & 2.2 & 2.1 & 1.1 & 13.8 \\
\hline Corchorus olitorius & Tiliaceae & NP & NP & 2.2 & NP & NP & NP & $N P$ & NP & NP & NP \\
\hline Crotalaria brevidens & Fabaceae & 37.5 & 15.4 & 32.6 & 33.3 & 30.8 & NP & $N P$ & NP & 1.2 & NP \\
\hline Crotolaria pycnostachya & Fabaceae & NP & 1.5 & NP & 2.9 & 3.1 & 2.8 & 1.1 & 2.3 & NP & NP \\
\hline Dyschoriste radicans & Acanthaceae & 1.4 & 12.3 & 10.9 & 7.3 & 6.2 & NP & NP & 3.2 & NP & NP \\
\hline Evolvulus alsinoides & Convulvulaceae & 12.5 & 6.2 & 10.9 & 4.4 & 3.1 & NP & 1.1 & NP & NP & NP \\
\hline Euphorbia inequilatera & Euphorbiaceae & NP & 1.5 & NP & NP & NP & 5.2 & 9.8 & 5.6 & 26.4 & NP \\
\hline Glycine wightii & Fabaceae & 14.9 & 12.3 & 17.4 & 14.4 & 13.9 & NP & 1.1 & 1.1 & NP & 1.1 \\
\hline Hypoestes verticillaris & Acanthaceae & NP & 1.5 & NP & NP & NP & 3.8 & 10.0 & 5.3 & 1.2 & 6.4 \\
\hline Indigofera brevicalyx & Fabaceae & 5.6 & 1.5 & 2.2 & 15.9 & 4.6 & 1.4 & $N P$ & 1.1 & 6.9 & 1.1 \\
\hline Indigofera spicata & Fabaceae & 2.8 & 1.5 & 10 & 3.6 & 21.5 & 19.5 & 8.2 & 10.4 & NP & 22.3 \\
\hline Indigofera volkensii & Fabaceae & NP & 26.7 & NP & NP & 1.5 & 19.5 & 14.4 & 23.4 & NP & 22.3 \\
\hline Ipomea mombassana & Convulvulaceae & NP & 1.5 & NP & NP & NP & $N P$ & 14.7 & 10.4 & 12.6 & 8.5 \\
\hline Launaea cornuta & Asteraceae & 5.7 & 1.1 & 3.2 & 3.1 & 2.1 & 3.7 & $N P$ & 4.2 & 19.5 & 10.6 \\
\hline Leucas martinicensis & Lamiaceae & 1.4 & NP & NP & NP & NP & 2.8 & 2.2 & 4.2 & 9.2 & 4.2 \\
\hline Ocimum basilicum & Lamiaceae & NP & 3.1 & 2.2 & 1.5 & NP & 5.6 & 1.1 & 1.1 & 3.4 & 2.1 \\
\hline Phyllanthus maderaspatensis & Phyllanthaceae & 1.4 & NP & NP & NP & NP & NP & 3.3 & NP & 3.5 & NP \\
\hline Polygala sphenoptera & Polygalaceae & 1.4 & NP & NP & 1.5 & 3.1 & NP & $N P$ & NP & NP & NP \\
\hline Rhynchosia minima & Fabaceae & 1.4 & NP & NP & NP & NP & NP & 3.3 & NP & 2.3 & 1.1 \\
\hline Ruellia patula & Acanthaceae & 4.2 & 4.6 & 4.4 & 7.3 & 6.2 & NP & 3.3 & NP & 2.3 & 1.1 \\
\hline Senna mimosoides & Fabaceae & NP & NP & 2.2 & NP & NP & 2.8 & 2.2 & 1.1 & 2.3 & NP \\
\hline Sida cuneifolia & Malvaceae & NP & 3.1 & NP & NP & NP & 2.8 & 2.2 & 1.1 & 2.3 & NP \\
\hline Solanum incanum & Solanaceae & 1.4 & NP & NP & 2.4 & 1.5 & 4.7 & 3.3 & NP & NP & NP \\
\hline Thunbergia alata & Acanthaceae & NP & 1.5 & 2.2 & NP & NP & 12.3 & 12.1 & 11.7 & 4.4 & NP \\
\hline Thunbergia elliotii & Acanthaceae & NP & NP & NP & NP & NP & NP & $N P$ & NP & NP & 1.1 \\
\hline Vigna membranaceae & Fabaceae & NP & NP & 2.2 & 1.5 & NP & NP & $N P$ & NP & NP & NP \\
\hline
\end{tabular}

NP not present

observed at $20 \mathrm{~m}$ from the river and the dam $(4.5 \pm 0.5)$ compared to a similar distance from the trough $(3.0 \pm$ $0.5)$, species richness was not significantly different between piospheres $(F=0.39, P=0.536)$ and seasons $(F=$ $3.25, P=0.780$ ). Interactions between treatments (distance $\times$ season $\times$ piosphere) were also not significant $(F$ $=0.34, P=0.950$ ).

Pielou evenness significantly increased $(F=7.47, P=$ 0.001 ) with distance from the three piospheres. However, Pielou evenness was not significantly different between piospheres $(F=3.05, P=0.052)$ but was higher at $20 \mathrm{~m}$ near the dam $(0.8 \pm 0.5)$ compared to a similar distance from the trough $(0.7 \pm 0.1)$ and the river $(0.7 \pm 0.1)$. Species evenness was also not significantly different between the wet and dry seasons $(F=0.24, P=0.629)$. Besides, there was no significant interactions between treatments (distance $\times$ season $\times$ piosphere $)(F=0.75, P=0.648)$.

\section{Discussion}

\section{Species composition}

More grass species were observed during the wet season compared to the dry season. This was because some of the ephemerals like $S$. verticillata were present only during the wet season. Ephemerals are grass species which regenerate immediately after the rains (Verdoodt et al. 2010; Lugusa et al. 2016), emerging where decreaser species have been depleted as a result of heavy grazing and are therefore a sign of poor range condition (Oluwole 
Table 3 Plant species Shannon-Wiener diversity index, richness, and Pielou evenness (mean \pm SE) at various piospheric distances

\begin{tabular}{|c|c|c|c|c|c|c|c|c|c|c|c|}
\hline \multicolumn{7}{|l|}{ Dry season } & \multicolumn{5}{|c|}{ Wet season } \\
\hline Piosphere & Distance (m) & 20 & 40 & 60 & 80 & 100 & 20 & 40 & 60 & 80 & 100 \\
\hline \multirow[t]{3}{*}{ Dam } & Diversity & $0.9 \pm 0.1 a$ & $1.2 \pm 0.1 \mathrm{a}$ & $1.1 \pm 0.4 a$ & $1.5 \pm 0.1 \mathrm{a}$ & $1.8 \pm 0.1 \mathrm{a}$ & $0.7 \pm 0.1 a$ & $0.9 \pm 0.2 a b$ & $1.16 \pm 0.1 \mathrm{bc}$ & $1.5 \pm 0.2 \mathrm{~cd}$ & $1.7 \pm 0.3 d$ \\
\hline & Richness & $4.5 \pm 0.5 a$ & $5.5 \pm 1.1 \mathrm{ab}$ & $6.5 \pm 0.3 b c$ & $7.3 \pm 0.5 b c$ & $8.0 \pm 0.0 c$ & $4.8 \pm 1.1 \mathrm{a}$ & $5.6 \pm 0.8 a$ & $6.25 \pm 0.9 a$ & $7.0 \pm 0.7 a$ & $7.5 \pm 0.5 a$ \\
\hline & Evenness & $0.8 \pm 0.5 \mathrm{ab}$ & $0.8 \pm 0.1 \mathrm{a}$ & $0.87 \pm 0.1 \mathrm{ab}$ & $0.9 \pm 0.2 \mathrm{ab}$ & $0.9 \pm 0.1 b$ & $0.8 \pm 0.1 a$ & $0.8 \pm 0.2 \mathrm{a}$ & $0.84 \pm 0.2 \mathrm{a}$ & $0.9 \pm 0.2 \mathrm{a}$ & $0.9 \pm 0.1 a$ \\
\hline \multirow[t]{3}{*}{ Trough } & Diversity & $0.8 \pm 0.2 a$ & $0.9 \pm 0.1 \mathrm{a}$ & $1.3 \pm 0.2 \mathrm{ab}$ & $1.3 \pm 0.1 \mathrm{ab}$ & $1.6 \pm 0.3 b$ & $1.1 \pm 0.1 \mathrm{a}$ & $1.4 \pm 0.2 \mathrm{ab}$ & $1.5 \pm 0.1 b$ & $1.6 \pm 0.1 b$ & $1.7 \pm 0.1 b$ \\
\hline & Richness & $3.0 \pm 0.5 a$ & $3.8 \pm 0.3 a b$ & $5.0 \pm 0.8 a b$ & $4.8 \pm 0.5 \mathrm{ab}$ & $5.3 \pm 1.0 b$ & $4.3 \pm 0.5 a$ & $5.3 \pm 1.1 \mathrm{a}$ & $5.8 \pm 0.8 \mathrm{a}$ & $6.3 \pm 0.4 a$ & $6.5 \pm 0.7 a$ \\
\hline & Evenness & $0.7 \pm 0.1 \mathrm{a}$ & $0.7 \pm 0.1 \mathrm{a}$ & $0.8 \pm 0.1 \mathrm{ab}$ & $0.8 \pm 0.3 a b$ & $0.9 \pm 0.3 b$ & $0.7 \pm 0.1 \mathrm{a}$ & $0.8 \pm 0.2 b$ & $0.9 \pm 0.1 b$ & $0.9 \pm 0.1 b$ & $0.9 \pm 0.1 b$ \\
\hline \multirow[t]{3}{*}{ River } & Diversity & $1.2 \pm 0.1 \mathrm{a}$ & $1.3 \pm 0.2 \mathrm{ab}$ & $1.6 \pm 0.1 b c$ & $1.7 \pm 0.1 c$ & $1.9 \pm 0.8 c$ & $1.2 \pm 0.2 \mathrm{a}$ & $1.3 \pm 0.1 \mathrm{ab}$ & $1.6 \pm 0.1 \mathrm{ab}$ & $1.6 \pm 0.1 \mathrm{ab}$ & $1.7 \pm 0.9 b$ \\
\hline & Richness & $4.5 \pm 0.5 a$ & $4.5 \pm 0.3 a$ & $4.3 \pm 1.1 \mathrm{a}$ & $5.5 \pm 0.5 \mathrm{ab}$ & $7.5 \pm 0.9 b$ & $3.0 \pm 0.4 a$ & $3.5 \pm 0.7 a b$ & $4.5 \pm 0.3 b c$ & $5.3 \pm 0.2 \mathrm{bd}$ & $6.5 \pm 0.3 d$ \\
\hline & Evenness & $0.7 \pm 0.1 a$ & $0.8 \pm 0.1 \mathrm{a}$ & $0.7 \pm 0.2 \mathrm{a}$ & $0.9 \pm 0.1 a$ & $0.9 \pm 0.1 \mathrm{a}$ & $0.6 \pm 0.1 \mathrm{a}$ & $0.8 \pm 0.04 b$ & $0.8 \pm 0.0 \mathrm{~b}$ & $0.9 \pm 0.1 b$ & $0.8 \pm 0.1 b$ \\
\hline
\end{tabular}

Means with different letters in the same row are significantly different $(P \leq 0.05)$

et al. 2008). Eragrostis spp., for instance, are increaser species, increasing in abundance where there is severe grazing that leads to range degradation (Du Toit 2009). These results corroborate Egeru et al. (2015) who observed 34 species during the wet season and 26 species during the dry season in Karamoja sub-region of Uganda. As reported by Sabiiti and Teka (2004) and Machogu (2013), Chloris, Hyparrhenia, Aristida, and Sporobolus spp. are some of the most pronounced grasses in the East African rangelands due to their selfseeding ability, tolerance to drought, and spreading capacity.

The results suggest that most grasses were more prevalent away from the piospheres, while forbs were predominant near the piospheres. This was probably because most grasses were decreaser species and therefore susceptible to grazing. Aristida spp., Hyparrhenia spp., Bothriochloa spp., T. triandra, and S. holstii are decreaser species (Angassa 2014). Grazing alters species composition within the rangeland ecosystems (Todd 2006; Wu et al. 2009). High grazing pressure reduces the density of palatable plants forcing the animals to forage on species of low nutrition value (Amiri et al. 2008). As such, most preferred plant species cease to grow, giving way for the proliferation of forbs (Chaichi et al. 2005; Loydi et al. 2012). Similar observations were made by Hoshino et al. (2009) who reported that species composition changes along grazing gradients are characterized by changes in density and cover of life forms, and annual species and forbs replace perennial grasses near the piospheres. The results are consistent with Mudongo et al. (2016) who observed that continuous grazing led to diminished perennial grass population and increase in forbs and woody species in the Kalahari rangelands of Botswana. Furthermore, the findings under this study corroborate those of Mureithi et al. (2010) who reported a prevalence of forbs under heavy grazing in the Njemps Flats of Kenya. Similar observations were also made by
Todd (2006) in the Nama-Karoo rangelands of Southern Africa where forbs and annual grasses replaced palatable perennial grasses due to heavy grazing near the piospheres. C. dactylon was, however, more pronounced near the water points. This was because $C$. dactylon can withstand heavy grazing, is extremely tolerant to fire, and adapts to various climatic and edaphic conditions, in addition to being tolerant to both salinity and flooding (Rita et al. 2012; Egeru et al. 2015). In a related study in the Sonamarg area of the Kashmir Himalayas, Mir et al. (2015) also observed that the importance value index of $C$. dactylon significantly increased during peak grazing seasons. Cynodon dactylon, Chloris pycnothrix, Eragrostis tenuifolia, and Sporobolus discosporus decreased with distance away from the piospheres. These findings corroborate the observations of Oluwole et al. (2008) that C. dactylon, Sporobolus spp., and Eragrostis spp. increase near the piospheres.

\section{Shannon-Wiener diversity index, species richness, and Pielou evenness}

Trampling and defoliation observed near the piospheres could justify the significantly lower plant species diversity, richness, and evenness. Due to higher animal concentration near the piospheres, there was greater plant defoliation that hampered seed germination, plant growth, and development. Besides, increased trampling slowed down plant regeneration upon grazing therefore reducing species richness and diversity. Further, hoof action could have led to soil compaction hindering infiltration of water and consequently low plant growth (Mapfumo et al. 2000). As reported by Amiri et al. (2008), soil compaction also triggers depletion of soil organic matter, which hampers the growth of plant species. Defoliation, excretion, and seed dispersal by grazing animals influence plant diversity (Duncan 2005). Animal excreta improve nutrient and water cycling which favors growth of palatable species and augment soil organic 
matter leading to fertile range soils that provide optimum condition for plant growth and improved rangeland health and productivity (Todd-Brown et al. 2014). Light or moderate herbivory increase plant diversity. Continuous grazing leads to overuse of forage, reducing their quality and quantity particularly during the reproductive stage. Heavy herbivory has been known to result in death of species and repetitive reproductive failure (Brooks and Matchett 2006; Todd 2006). Besides, overgrazing hampers seed germination and consequently inhibits plant growth and development further reducing vegetation cover, soil hydraulic conductivity, and nutrients available to plants (Amiri et al. 2008). These findings corroborate those of Angassa (2014) who observed that $80 \%$ of herbaceous species exhibited a high vulnerability to grazing in the Borana region of Southern Ethiopia. Shahriary et al. (2012) also reported a decrease in species richness with increased grazing intensity around the piospheres of Iran. Similarly, Socher et al. (2013), Meyers et al. (2014), and Haynes et al. (2013) also observed that heavy grazing reduces plant species diversity richness and evenness. Mureithi et al. (2014) also reported that diversity of herbaceous species abundance and richness was higher in mildly to moderately grazed areas compared to heavily grazed areas in Northwestern Kenya. Besides, Todd (2006), while conducting a similar study in the Nama-Karoo rangelands of South Africa, observed that there were twice as many species further from the piospheres as nearer the piospheres.

No significant difference in plant diversity, richness, and evenness was observed between seasons. This could be due to the fact that 18 out of the 22 grass species observed were perennials (Table 1) and had life-spans of more than a season. The four annuals observed (C. pycnothrix, E. tenuifolia, E. fatmensis, and $S$. verticillata) were not sufficient to produce a significant difference. Similarly, at least 25 out of the 29 forbs were observed during both dry and wet seasons (Table 2), with the exception of Thunbergia elliotii and Polygala sphenoptera which were not recorded in the wet season and Corchorus olitorius and Becium obovatum which were not recorded in the dry season. The findings could be attributed to the fact that the study area was mainly dominated by $S$. holstii and $T$. triandra (Table 1) which are perennial grasses. Most forbs observed were also perennial and survived for more than a season. Pre-dominance of perennial grasses during dry and wet seasons was also observed by Egeru et al. (2015) in the Karamoja sub-region of Uganda. As noted by Kasale (2013) and Wesuls et al. (2013), perennial grasses possess a self-seeding characteristic, are tolerant to drought, and have a spreading capacity that enable them to develop good cover and hence survive both seasons.

Differences in landscape use, however, led to significantly higher plant diversity being observed around the seasonal river compared to the dam and trough. It was observed that livestock grazed as they walked along the river thereby evenly distributing grazing pressure as opposed to around the dam and trough where animals concentrated around the same point. The river was long and therefore provided the grazing animals with a large surface area for foraging. This evenly distributed grazing pressure along the river reducing animal impact on vegetation, hence the higher species diversity. Similar results were observed by Egeru et al. (2015) in the Karamoja sub-region of Uganda who attributed the observations to varying use of landscape, piosphere location, and herder characteristics. The results further corroborate those $\mathrm{Hu}$ et al. (2015) that herd movements impacted on species composition, diversity, and richness.

\section{Implications for management}

The results from this study point to consistent and severe alterations in plant composition and diversity that are possibly attributable to the cumulative long-term consequences of piosphere-concentrated grazing. The impact could potentially be greater, owing to the proliferation of piospheres in the Kenyan rangelands as a water intervention measure. Range managers should therefore seek conservation measures that can sustainably protect forage species that are sensitive to grazing. Grazing exclusions have been known to preserve plant species composition in most rangelands of the world Todd (2006). This is because these rest periods allow for plant regeneration and seed bank restoration after seasons of intense trampling and defoliation.

\section{Conclusions}

The study demonstrated that areas near the piospheres have been heavily grazed by animals thereby reducing plant species Shannon-Wiener diversity and richness. It is recommended that grazing animals be placed under strict monitoring to reduce the amount of time spent around the piospheres. Alternatively, range reseeding should also be done to rehabilitate the areas that are already degraded. These are expected to improve livestock production and enhance pastoral livelihoods.

\section{Acknowledgements \\ This study was funded by the International Canopy of Conservation (I-CAN) facilitated by the African Conservation Centre (ACC) through the African Drylands Institute for Sustainability (ADIS) at the University of Nairobi. We also acknowledge Musembi J for his help in vegetation sampling and species identification. Special thanks to the management of Mopel Ranch, Kiserian, for allowing us to conduct the research within their premises.}

\section{Authors' contributions}

JS designed the study, collected the data, and participated in the data analysis and drafted manuscript write-up and revision. KO was part of the study design, data cleaning, analysis, and manuscript write-up and revision. KG was part of the study design, data analysis and presentation, and manuscript editing. MJ was part of the research design and methodology, 
and data analysis and contributed to the result write-up and manuscript editing. All authors read and approved the final manuscript.

\section{Competing interests}

The authors declare that they have no competing interests.

\section{Publisher's Note}

Springer Nature remains neutral with regard to jurisdictional claims in published maps and institutional affiliations.

Received: 16 November 2016 Accepted: 11 April 2017

\section{Published online: 05 May 2017}

\section{References}

Amiri ME, Fallahi E, Golchin A (2008) Influence of foliar and ground fertilization on yield, fruit quality, and soil, leaf, and fruit mineral nutrients in apple. J Plant Nutr 31(3):515-525

Angassa A (2014) Effect of grazing intensity and bush encroachment on herbaceous species and rangeland condition in southern Ethiopia. Land Degrad Dev 25(5):438-451

Bekure, S (1991) Maasai herding: an analysis of the livestock production system of Maasai pastoralists in eastern Kajiado District, Kenya (Vol. 4). ILRI (aka ILCA and ILRAD)

Brooks ML, Matchett JR (2006) Spatial and temporal patterns of wildfires in the Mojave Desert, 1980-2004. J Arid Environ 67:148-164

Chaichi MR, Saravi MM, Malekian H (2005) Effects of livestock trampling on soil physical properties and vegetation cover (case study: Lar Rangeland, Iran). Int J Agric Biol 7:904-908

de Leeuw, PN, Grandin, BE, Bekure, S (1991) Introduction to the Kenyan rangelands and Kajiado district. Maasai herding: an analysis of the livestock production system of Maasai pastoralists in eastern Kajiado District, Kenya, 92-9053

Du Toit JCO (2009) Early survival and growth of vegetatively propagated indigenous grasses in a clear-felled timber plantation in Kwa Zulu-Natal, South Africa. Afr J Range Forage Sci 26(2):97-101

Duncan A (2005) Farm animals and biodiversity. Anim Sci 81:187-188

Egeru, A (2014) Assessment of forage dynamics under variable climate in Karamoja sub-region of Uganda. Unpublished PhD thesis, University of Nairobi, pp. 25[42]

Egeru A, Wasonga O, MacOpiyo L, Mburu J, Tabuti JR, Majaliwa MG (2015) Piospheric influence on forage species composition and abundance in semiarid Karamoja sub-region, Uganda. Pastoralism 5(1):1

Haynes MA, Fang Z, Waller DM (2013) Grazing impacts on the diversity and composition of alpine rangelands in Northwest Yunnan. J Plant Ecol 6(2): 122-130

Hoshino A, Yoshihara Y, Sasaki T, Okayasu T, Jamsran U, Okuro T, Takeuchi K (2009) Comparison of vegetation changes along grazing gradients with different numbers of livestock. J Arid Environ 73(6):687-690

Hu FL, Liu B, Liu ZM, Fang YT, Busso CA (2015) Effects of grazing on plant species diversity and carbon partitioning in semiarid rangelands of northeastern China. Phyton Int J Exp Bot 84:209-221

Hunt JE, Kelliher FM, McSeveny TM, Byers JN (2002) Evaporation and carbon dioxide exchange between the atmosphere and a tussock grassland during a summer drought. Agric Forest Meteorology 111(1):65-82

Kareri, R (2013) Some aspects of the geography of Kenya. In Proceedings of the 2010 Indiana University-Perdue University Indianapolis (IUPUI) Fulbright Hays Group Projects Symposium, Eldoret, Kenya (Vol. 9).

Kasale, F, (2013) Determination of nutritive values of browsable plants utilized by cattle during the dry season in Sibbinda constituency of Zambezi RegionNamibia. Master Thesis. University of Namibia [40]

Kioko J, Okello MM (2010) Land use cover and environmental changes in a semiarid rangeland, Southern Kenya. J Geography Regional Plann 3(11):322

Krebs CJ (1989) Ecological methodology. Harper Collins Inc., New York

Krhoda, G (2002) Nairobi river basin phase II: the monitoring and sampling strategy for Ngong.

Landman M, Schoeman DS, Hall-Martin AJ, Kerley GI (2012) Understanding longterm variations in an elephant piosphere effect to manage impacts. PLoS ONE 7(9):e45334

Lange, RT (1969) The piosphere: sheep track and dung patterns. Journal of Range Management, 396-400
Loydi A, Zalba SM, Distel RA (2012) Vegetation change in response to grazing exclusion in montane grasslands, Argentina. Plant Ecology Evolution 145(3):313-322

Lugusa KO, Wasonga OV, Elhadi YA, Crane TA (2016) Value chain analysis of grass seeds in the drylands of Baringo County, Kenya: a producers' perspective. Pastoralism 6(1):1

Machogu, C (2013) A comparative study of the productivity of Brachiaria hybrid Cv. Mulato II and native pasture species in semi-arid rangelands of Kenya. Master Thesis University of Nairobi

Mapfumo E, Chanasyk S, Baron S, Naeth A (2000) Grazing impacts on selected soil parameters under short-term forage sequences. J Rang Mgt 53(5):466470 , Society for range management

Meyers LM, DeKeyser ES, Norland JE (2014) Differences in spatial autocorrelation (SAc), plant species richness and diversity, and plant community composition in grazed and ungrazed grasslands along a moisture gradient, North Dakota, USA. Appl Veg Sci 17(1):53-62

Middleton, N, and Thomas, D. (1997) World atlas of desertification (No. Ed. 2) Arnold, Hodder Headline, PLC

Mir, FA, Bhat, GA, Sheer, BA, Khan, AG (2015) Impacts of seasonal livestock grazing on plant community features: a case study on grazing pastures at Sonamarg area in Kashmir Himalaya. J Agric Sci. 10(1)

Mudongo, El, Fusi, T, Fynn, RW, Bonyongo, MC (2016) The role of cattle grazing management on perennial grass and woody vegetation cover in semiarid rangelands: insights from two case studies in the Botswana Kalahari

Mureithi, SM, Verdoodt, A, Van Ranst, E (2010) Effects and implications of enclosures for rehabilitating degraded semi-arid rangelands: critical lessons from Lake Baringo Basin, Kenya. In Land degradation and desertification: assessment, mitigation and remediation (pp. 111-129). Springer Netherlands

Mureithi, SM., Verdoodt, A, Njoka, JT, Gachene, CK., Warinwa, F, Van Ranst, E (2014) Impact of community conservation management on herbaceous layer and soil nutrients in a Kenyan semi-arid savannah land degradation and development

Ogutu JO, Owen-Smith N, Piepho HP, Said MY, Kifugo S, Reid RS, Andanje S (2013) Changing wildlife populations in Nairobi National Park and adjoining Athi-Kaputiei Plains: collapse of the migratory wildebeest. Open Conser Biol J 7:11-26

Oluwole F, Sambo J, Sikhalazo D (2008) Long-term effects of different burning frequencies on the dry savannah grassland in South Africa. Afr J Agric Res 3(2):147-153

Ombogo, MO. (2013).The impact of climate variability on pastoralism: forage dynamics and trends in cattle population in Kajiado County, Kenya. Doctoral dissertation, University of Nairobi

Opiyo F, Wasonga O, Nyangito M, Schilling J, Munang R (2015) Drought adaptation and coping strategies among the Turkana pastoralists of northern Kenya. Int J Disaster Risk Sci 6(3):295-309

Riginos C, Hoffman MT (2003) Changes in population biology of two succulent shrubs along a grazing gradient. J Appl Ecol 40(4):615-625

Rita P, Aninda M, Animesh DK (2012) An updated overview on Cynodon dactylon (L.) Pers. IJRAP 3(1):11-14

Sabiiti, EN, Teka, T (2004) Dryland husbandry in Uganda: community participation and development. Ossrea

Shahriary E, Palmer MW, Tongway DJ, Azarnivand H, Jafari M, Saravi MM (2012) Plant species composition and soil characteristics around Iranian piospheres. J Arid Environ 82:106-114

Smet M, Ward D (2006) Soil quality gradients around water-points under different management systems in a semi-arid savanna, South Africa. J Arid Environ 64(2):251-269

Socher SA, Prati D, Boch S, Müller J, Baumbach H, Gockel S, Kalko EK (2013) Interacting effects of fertilization, mowing and grazing on plant species diversity of 1500 grasslands in Germany differ between regions. Basic and Applied Ecology 14(2):126-136

Tarhouni M, Belgacem AO, Neffati M, Henchi B (2007) Qualification of rangeland degradation using plant life history strategies around watering points in southern Tunisia. Pakistan journal of biological sciences: PJBS 10(8):1229_ 1235

Todd SW (2006) Gradients in vegetation cover, structure and species richness of Nama-Karoo shrublands in relation to distance from livestock watering points. J Appl Ecol 43(2):293-304

Todd-Brown KEO, Randerson JT, Hopkins F, Arora V, Hajima T, Jones C, Shevliakova $E$ (2014) Changes in soil organic carbon storage predicted by Earth system models during the 21st century. Bio-geosciences 11(8):23412356 
Verdoodt A, Mureithi SM, Van Ranst E (2010) Impacts of management and enclosure age on recovery of the herbaceous rangeland vegetation in semiarid Kenya. J Arid Environ 74(9):1066-1073

Wesuls D, Pellowski M, Suchrow S, Oldeland J, Jansen F, Dengler J (2013) Grazing fingerprint: modelling species responses and trait patterns along grazing gradients in semi-arid Namibian rangelands. Ecol Indic 27:61-70 [41]

Wu GL, Du GZ, Liu ZH, Thirgood S (2009) Effect of fencing and grazing on a Kobresia-dominated meadow in the Qinghai-Tibetan Plateau. Plant Soil 319: $115-126$

Submit your manuscript to a SpringerOpen ${ }^{\mathcal{O}}$ journal and benefit from:

- Convenient online submission

- Rigorous peer review

- Immediate publication on acceptance

- Open access: articles freely available online

- High visibility within the field

- Retaining the copyright to your article

Submit your next manuscript at springeropen.com 